\title{
Retrovirus infections among patients treated in Britain with various clotting factors
}

\author{
R CHEINSONG-POPOV, R S TEDDER, T O'CONNOR, S CLAYDEN, A SMITH, \\ J CRASKE, R WEISS
}

\begin{abstract}
At the end of 1984 a collaborative survey was carried out to determine the prevalence of infection with human $T$ cell lymphotropic virus type III/lymphadenopathy associated virus (HTLV-III/LAV) and HTLV-I among 584 recipients of various blood products in Britain at that time. In 204 cases yearly point prevalence figures for infection were also obtained for 1978 to 1983.

In 1984,215 of 315 patients $(68 \%)$ who had received commercial concentrate for haemophilia $A$ were identified as positive for anti-HTLV-III/LAV as compared with only 18 of 166 patients (11\%) given British concentrate alone for this disease. This difference was further emphasised by the yearly point prevalence rates: seroconversion began in 1980 among recipients of commercial concentrate, but not until 1983 did such an instance occur among recipients of British concentrate.

Any conclusions must remain speculative, but possibly seropositivity among haemophiliacs may not carry so grave a prognosis as previously thought.
\end{abstract}

\section{Introduction}

The identification of the human $T$ cell lymphotropic virus type III/lymphadenopathy associated virus (HTLV-III/LAV $)^{12}$ and the development of sensitive and specific assays for detecting antibody to it (anti-HTLV-III/LAV) have permitted studies to define the prevalence of viral infection in groups at risk for the acquired immune deficiency syndrome (AIDS). We describe the results of a collaborative survey undertaken at the end of 1984 to define the prevalence of HTLV-III/LAV and HTLV-I infections among recipients in Britain of various blood products at that time.

\section{Patients and methods}

We examined 1040 serum samples from 584 patients undergoing treatment with clotting factors in Britain for various clotting disorders. All patients were bled during 1984, and when more than one sample was available for study only the most recent was used. In addition, serum specimens taken during 1978 to 1983 were available from a cohort of 204 of the patients being treated for factor VIII deficiency. Serum specimens from these patients were studied for each year, and when more than one specimen was available for each year only the most recent was used.

Serum or plasma specimens, native and heat inactivated, previously stored at $-20^{\circ} \mathrm{C}$ were tested for anti-HTLV-III/LAV by an enzyme linked

Institute of Cancer Research, Chester Beatty Laboratories, London SW7 R CHEINGSONG-POPOV, PHD, scientist S CLAYDEN, BSC, technician

R WEISS, PHD, FRCPATH, professor

Section of Virology, Microbiology Department, Middlesex Hospital and University College Medical Schools, London W1P 7PP

R S TEDDER, MRCPATH, consultant virologist

T O'CONNOR, BSC, research medical laboratory scientific officer

A SMITH, PHD, research assistant

Public Health Laboratory, Withington Hospital, Manchester M20 8LR

J CRASKE, MB, MRCPATH, consultant virologist

Correspondence to: Dr Tedder. immunosorbent assay modification of a previously described radio immunoassay which was considered free from interference through freez thawing, ${ }^{3}$ heat inactivation of serum, and the presence of antilymphocy? antibodies. Serum samples from patients with haemophilia A were also tested for antibody to HTLV-I by a competitive enzyme linked immunō sorbent assay modification of the method previously described. ${ }^{4}$

Patients were grouped into those with haemophilia A (factor VIf deficiency) and those with haemophilia B (factor IX deficiency). Thirty two patients, including those with other factor deficiencies, von Willebrand's disease, or acquired clotting deficiencies, made up a small miscellaneous. group. Patients with inherited factor VIII deficiency were divided accordin $\overrightarrow{\mathbf{E}}$ to their treatment since 1978 into those who had received any commercia factor VIII concentrate and those receiving British prepared factor VI concentrate only.

\section{Results and discussion}

In 1984 the greatest burden of infection was borne by patient who had received commercial factor VIII concentrate in the preceding five years (table I). Roughly two thirds of such patients were seropositive. By contrast, only 18 patients among 166 who had received British factor VIII exclusively were seropositive. At the time of study 15 of these cases were accounted for by infection arising in a group of 33 Scottish haemophiliacs given a uniquel $\vec{b}$ infectious batch of British concentrate. . Outside this group onlg $^{\circ}$ three infections appeared to have occurred by 1984 in the remaining 132 patients exclusively treated with British factor VIII conceno trate. These data suggest that up to 1984 the risk of acquirin infection from using native British concentrates was present bu low, reflecting the low prevalence of HTLV-III/LAV infected donors among the voluntary donor panels in the United Kingdom?. Since it was difficult to exclude occasional rare exposure t $\overrightarrow{\vec{\theta}}$ commercial concentrate-for example, some patients shared con $\beta$ centrates with visiting affected brothers-it is possible that these infections may not necessarily have arisen from the British concen trates.

The contrast in the prevalence of infection between recipients of volunteer and of commercial donor products was shown by the 1984 prevalence data and further emphasised by the yearly poir. prevalence figures for seropositivity in haemophiliacs (table II Seroconversion began in this group as early as 1980 and continued through 1981 and 1982 - a finding previously noted by Professer L Luzzatto, ${ }^{\zeta_{2}}$ whose data are included. HTLV-III/LAV infections have only recently become established in British homosexuals ${ }^{67}$ anep it is therefore not surprising that the emergence of infection in thos patients receiving commercial concentrate paralleled more near seropositivity for drug addicts and homosexuals in the United States. If this proves to be the case, then the outcome seropositivity in haemophiliacs may perhaps be less grave than has been suggested. ${ }^{8}$ Besides HTLV-III/LAV, it was known that HTLV-I and HTLV-II were also prevalent in the subjects at risk ff्c

TABLE I-Anti-HTLV-III/LAV in 584 patients having treatment for clotti啇 disorders

\begin{tabular}{|c|c|c|}
\hline Patient group & No tested & No $(\%)$ positi民 \\
\hline \multicolumn{3}{|l|}{ Factor VIII deficient: } \\
\hline Treated with any commercial concentrate & 315 & $215(68)$ \\
\hline Treated with British concentrate only & 166 & 18 (11) 미 \\
\hline Factor IX deficient & 71 & $4(6)=$ \\
\hline Miscellaneous & 32 & $2(6)$ \\
\hline
\end{tabular}


BRITISH MEDICAL JOURNAL VOLUME 29319 JULY 1986

TABLE II-Anti-HTLV-III/LAV in patients with haemophilia $A$ having treatment with commercial or British factor VIII concentrate

\begin{tabular}{ccccc}
\hline & \multicolumn{2}{c}{ Commercial } & \multicolumn{2}{c}{ British } \\
\cline { 2 - 3 } \cline { 5 - 5 } Year of testing & No tested & No $(\%)$ positive & No tested & No (\%) positive \\
\hline 1978 & 10 & 0 & 2 & 0 \\
1979 & 28 & 0 & 2 & 0 \\
1980 & 70 & $23(33)$ & 2 & 0 \\
1981 & 56 & $28(50$ & 2 & 0 \\
1982 & 72 & $46(64)$ & 8 & 0 \\
1983 & 105 & $69(66)$ & 99 & $1(1)$ \\
1984 & 315 & $215(68)$ & 166 & $18(11)$ \\
\hline
\end{tabular}

TABLE III-Anti-HTLV-I in 401 patients with haemophilia A

\begin{tabular}{lcc}
\hline \multirow{2}{*}{$\begin{array}{l}\text { Serological finding } \\
\text { for HTLV-III }\end{array}$} & \multicolumn{2}{c}{ Anti-HTLV-I } \\
\cline { 2 - 3 } & No tested & No positive \\
\hline Positive & 120 & 0 \\
Negative & 281 & 1 \\
\hline
\end{tabular}

AIDS $^{4}$ and might be represented among the commercial donors. There was no evidence of HTLV-I infection in any patient with the exception of a single Japanese, who was seronegative for HTLVIII/LAV (table III). This finding accords with previous studies, ${ }^{9}$ showing that HTLV-I was not transmitted by blood products prepared from pooled plasma. The failure of HTLV-I to transmit was also likely to be due to a relatively low prevalence of infected donors and the presence of high concentrations of neutralising antibody in plasma from any infected donor. ${ }^{10}$

The prevalence of HTLV-III/LAV infection remained comparatively unchanged from 1982 onwards. This may have been due to the exclusion of high risk subjects from the commercial donor panels though this seems unlikely in view of the seroconversions documented in 1983 and 1984 . There are two alternative explanations: either these highly exposed but seronegative patients represented people relatively insusceptible to infection with HTLV-
III/LAV or they represented infected people in whom the virus was truly latent and unexpressed. If the second were true the virus might become actively expressed at any later time and would be associated with late seroconversion and the usual clinical sequelae to infection. We still have a great deal to learn with this new viral infection and only the passage of time and careful study may turn speculation into fact.

We thank Dr B Bennett, Professor A Bloom Dr B Colvin, Dr P Jones, Dr P Kernoff, Dr J Lilleyman, Dr C Ludlam, Professor L Luzzatto, Dr E Preston, Dr C Rizza, Dr G Savage, Dr G Scott, and our other very many colleagues looking after haemophiliac and other patients for their cooperation and permission to present these data. We also thank the Wellcome Foundation for providing HRPO conjugated anti-HTLV-III/LAV. This study was supported in part by the Haemophilia Society, Medical Research Council, and Cancer Research Campaign.

\section{References}

I Barre-Sinoussi F, Cherman JC, Rey F, et al. Isolation of a T-lymphotropic retrovirus from a patient at risk for acquired immune deficiency syndrome AIDS $>$. Science 1983;220:867-70.

2 Allo RC, Salahuddin SZ, Popovic M, et al. Frequent detection and isolation of cytopathic retroviruses (HTLV III) from patients with AIDS and at risk from AIDS. Science 1984;224: $500-3$

3 Cheingsong-Popov RC, Weiss RA, Dalgleish A, et al. Prevalence of antibody human Tlvmphotropic virus type III in AIDS and AIDS-risk patients in Britain. Lancet 1984;ii:477-80.

Tejder RS, Shanson D, Jeffries D, et al. Low prevalence in the UK of HTLV I and HTLV II infection in subjects with AIDS, with extended lymphadenopathy, and at risk of AIDS. Luncel infection in subie

5 Ludlam CA, Steel, CM, Cheingsong-Popov RC, et al. Human T-lvmphotropic virus type III (HTLV III) infection in seronegative haemophiliacs after transfusion of factor VIII. Lancet 1985;ii:233-6.

5a Ball SE, Hows JM, Worsley AM, et al. Seroconversion of $T$ cell lymphotropic virus III (HTLV-III) in patients with haemophilia; a longitudinal study. Br Med f 1985;290:1705-6.

6 Carne CA, Sutherland S, Ferns RB, et al. Rising prevalence of human T-lymphotropic virus type III (HTLV III) infection in homosexual men in London. Lancet 1985;ii:1261-2.

7 Mortimer PP, Jesson WJ, Vandervelde EM, Pereira MS. Prevalence of antibody to human T lymphotropic virus type III by risk group and area, United Kingdom 1978-84. Br Med $\mathcal{J}$ 1985;290:1176-8

8 Fuchs D, Dierich MP, Housen A, et al. Are homosexuals less at risk of AIDS than intravenous drug abusers and hacmophiliacs? Lancet 1985;ii:1130.

Okochi K, Sato H, Hinuma Y. A retrospective study on transmission of adult T-cell leukemia virus by blond transfusions: seroconversion in recipients. Vox Sang 1984;46:245-53.

10 Clapham P, Nagy K, Weiss RA. Pseudotypes of human T-cell leukemia virus types 1 and 2: neutralization by patients' sera. Proc Natl Acad Sci USA 1984;81:2886-9.

(Accepted 15 May 1986)

\title{
Short course of steroids in home treatment of children with acute asthma
}

\author{
A DESHPANDE, SHEILA A MCKENZIE
}

\begin{abstract}
A double blind, randomised, placebo controlled study of the treatment of children with acute asthma at home showed that a three day course of prednisolone hastened improvement of both asthmatic symptoms and peak expiratory flow rates. Thus all asthmatic children who present with an acute attack should be considered for treatment with corticosteroids in addition to bronchodilators not only to prevent possible deterioration but also to speed recovery.
\end{abstract}

Department of Paediatrics, Oldchurch Hospital, Romford, Essex

A DESHPANDE, $M D$, paediatric registrar

SHEILA A MCKENZIE, MRCP, DCH, consultant paediatrician

Correspondence and requests for reprints to: Dr S A McKenzie, Rush Green Hospital, Romford, Essex RM7 OYA.

\section{Introduction}

Corticosteroids are now generally accepted to be of value in the management of patients admitted to hospital with acute severe asthma. ${ }^{1}$ Their value for patients not admitted to hospital is less clear. These patients have by implication less severe asthma at the time of presentation, and it might be argued that improvement would occur just as quickly with corticosteroid treatment as without it. We conducted a study to examine whether a three day course of prednisolone speeded recovery in children with an acute episode of asthma managed at home. We assessed both symptomatic improvement and improvement in airways obstruction as measured by changes in peak expiratory flow rate (PEFR).

\section{Patients and methods}

Children with asthma who attended the paediatric chest clinic were eligible for admission to the study provided they could use a peak flow meter. 